\title{
Potential indicators of soil quality in temperate forest ecosystems: a case study in the Basque Country
}

\author{
Nahia GARTZIA-BENGOETXEA ${ }^{1 *}$, Ander GONZÁLEZ-ARIAS ${ }^{1}$, Ellen KANDELER $^{2}$, \\ Inazio MARTÍNEZ DE ARANO ${ }^{1}$
}

\begin{abstract}
${ }^{1}$ NEIKER-Tecnalia, Basque Institute for Agricultural Research and Development, Forestry Unit, Zamudio Technology Park 812,48160 Derio, Spain
${ }^{2}$ Institute of Soil Science and Land Evaluation, Soil Biology Section, University of Hohenheim, Emil Wolff-Str. 27, 70599 Stuttgart, Germany
\end{abstract}

Keywords:

species change /

logging /

soil indicator

Mots-clés :

changement d'espèces /

débardage /

indicateurs de sol
(Received 19 March 2008; accepted 16 Jaunary 2009)

\begin{abstract}
- Assessment of forest sustainability requires reliable soil quality indicators. The present study evaluated the use of several potential such indicators in forests in the Basque Country under different types of management, involving: (i) species change and (ii) heavily mechanised forest operations.

- Five adjacent forest stands were selected for study: (i) two unmanaged forests (Quercus robur, Fagus sylvatica) and one (40-year-old) Pinus radiata plantation, to investigate the effect of species change; and (ii) a chronosequence of mechanised radiata pine plantations ( 3 and 16 years old), to investigate heavy mechanisation.

- Several physical, chemical and biological parameters were analysed in the mineral soil. Species change could not be assessed with chemical parameters, but parameters related to organic matter indicated the disturbance caused by heavy mechanisation. The Least Limiting Water Range was a good indicator of soil physical degradation induced by heavy mechanisation. Biological parameters proved sensitive indicators: (i) the fungal phospholipid fatty acid biomarker 18:2 $\omega 6$ for species change; and (ii) the ratio of Gram-positive/Gram-negative bacteria for heavy mechanisation. Nevertheless, these parameters are complementary, and monitoring programmes should include physical, chemical and biological parameters.

- Further studies are required to assess natural boundaries of variation in soil quality indicators, and their resistance and resilience.
\end{abstract}

Résumé - Indicateurs potentiels de la qualité des sols dans les écosystèmes forestiers tempérés : une étude de cas dans le Pays Basque.

- L'évaluation de la durabilité des forêts nécessite des indicateurs fiables de la qualité des sols. La présente étude a évalué l'utilisation de plusieurs de ces indicateurs potentiels dans les forêts du Pays Basque sous différents types de gestion, comprenant : (i) le changement des espèces et (ii) les opérations forestières fortement mécanisées.

- Cinq peuplements forestiers voisins ont été sélectionnés pour l'étude : (i) deux forêts non gérées (Quercus robur, Fagus sylvatica) et une plantation (âgée de 40 ans) de Pinus radiata, pour examiner l'effet des changements d'espèces, (ii) une chronoséquence de plantations mécanisées de Pinus radiata (âgées de 3 et 16 ans), pour enquêter sur la mécanisation lourde.

- Plusieurs caractéristiques physiques, chimiques et biologiques ont été analysées dans le sol minéral. Le changement d'espèce ne peut être évaluée avec des paramètres chimiques, mais les paramètres liés à la matière organique ont indiqué des perturbations causées par la forte mécanisation. Le Least Limiting Water Range est un bon indicateur de la dégradation des sols induite par la forte mécanisation. Paramètres biologiques qui se sont révélés des indicateurs sensibles : (i) le biomarqueur acide gras phospholipide fongique 18:2 $\omega 6$ pour le changement d'espèces, (ii) le rapport bactérien Gram-positive/Gram-negative pour la mécanisation lourde. Néanmoins, ces paramètres sont complémentaires, et des programmes de suivi devraient inclure des paramètres physiques, chimiques et biologiques.

- D'autres études sont nécessaires pour évaluer les limites naturelles de la variation des indicateurs de la qualité des sols, de leur résistance et de leur résilience.

\footnotetext{
*Corresponding author: ngartzia@ neiker.net
} 


\section{INTRODUCTION}

Most European countries agreed to the Pan-European principles for sustainable forest management (MCPFE, 1993) because of the widespread conversion of native forests and afforestation of agricultural or abandoned land to provide cultivated forests of rapidly growing exotic species. Furthermore, the increasing demands by global markets and the intensification of logging operations (timber harvesting and site preparation) were placing greater pressure on forest ecosystems. In northern Spain, cultivated radiata pine (Pinus radiata D. Don) forests cover an area of more than 150000 ha, and semi-natural forests of European beech and pedunculate oak have been maintained in small patches (20000 ha). The current types of forest management in these cultivated plantations involve clearcutting with rotations of between 30 and $40 \mathrm{y}$, harvesting with chainsaws, skidding, and mechanical site preparation -prior to planting- by processes such as scarification and ripping. Such logging operations are usually considered to be critical for forest soil sustainability (Ranger et al., 2008).

Forests play a key role in global sustainability, for providing raw materials and also ecosystem functions related to biodiversity, carbon sequestration and protection of soil and water. Maintenance of these functions should be the goal of sustainable forest management (Doran, 2002). Assessment of the sustainability of forest management requires indicators, and as forestry has a large impact on soil systems, there is a need to develop indicators of soil-based sustainability; this need has become increasingly important since forest policies have shifted to more balanced ecological approaches. The main challenge in selecting indicators of soil quality lies in determining which variables characterise the system and yet are simple enough to be monitored effectively and efficiently (Dale et al., 2008).

Several authors have proposed minimum datasets of soil parameters to be used as soil quality indicators (Doran and Parking 1994, Tscherko and Kandeler 1999, Shukla et al., 2006). These datasets should define ecosystem processes that integrate physical, chemical and biological properties. Soil organic matter (SOM) has frequently been suggested as a key attribute of soil quality and sustainability (Nambiar, 1996). However, results of prior studies in cultivated forests were inconclusive in terms of the response of total SOM as an indicator of sustainable forest management (Bauhus et al., 2002). Therefore, different pools of SOM with different functional roles in soil should be evaluated. Particulate organic matter (POM) may respond more rapidly to management than SOM (Cambardella and Elliot, 1992) and the soil microbial community -a small but very active part of the SOM- has been proposed as a sensitive indicator of change in grassland and boreal ecosystems (Mariani et al., 2006; Tscherko et al. 2007).

The composition and function of microbial communities may be altered by changes in the quantity and biochemical composition of plant litter (Hassett and Zak, 2005) and by the effect of logging operations on soil microenvironments.

Soil physical quality is typically altered during timber harvesting by modification of the porosity and impedance of the movement of gas, water, nutrients and roots in the profile (Godefroid et al., 2007). The least limiting water range (LLWR) has been suggested as a promising indicator of physical soil disturbance (da Silva and Kay, 1997b; McKenzie and McBratney, 2001) as it incorporates the limiting factors for growth of vegetation -such as mechanical impedance, oxygen and water supply to plant roots- in a single parameter based on water content.

The main characteristic of a good indicator of forest sustainability is its ability to be compared with a benchmark and/or target that defines a sustainable level. Natural forests have been identified as representing such a sustainable level in terms of forest management. However, species have different effects on soil processes such as nutrient cycling, base content and humus formation. These effects are mainly attributed to the effect that differences in species -in terms of litter quality and root exudates- have on soil microorganisms (Leckie et al., 2004). It is therefore important to understand the differences in soil properties with respect to native and exotic species in order to establish reliable benchmarks for sustainable forestry.

In this context, the objectives of the present study were (i) to investigate the behaviour of a large set of parameters proposed as soil quality indicators, in adjacent stands that differ mainly in land-use history and management, but not in soil parent material, geomorphology or climate, and (ii) to obtain an insight into the potential use of these parameters as indicators of soil quality, for future planning of soil monitoring programmes in temperate forest ecosystems.

\section{MATERIALS AND METHODS}

\subsection{Site description}

The study site (5 ha) (30T 534075 4783284), which comprised five different forest stands, was selected as an example of the Atlantic forest landscape in the Basque Country. The stands were in close proximity, and all were developed on the same parent material (sandstone). The soil was classified as a Dystric Regosol, and textural and soil mineralogical conditions were homogeneous within the study site (Tab. I). Texture analysis was determined, after chemical dispersion with hydrogen peroxide $\left(\mathrm{H}_{2} \mathrm{O}_{2}\right)$, by laser diffractometry (Mastersizer 2000 particle size analyser, Malvern Instruments Ltd., Worcestershire, U.K.), and mineralogical characterisation was performed by X-ray diffraction (XRD), with a Philips PW-1710 X-ray automated diffractometer with automatic divergence slit, and $\mathrm{Ni}$ filtered and monochromated $\mathrm{Cu} \mathrm{K} \alpha$ radiation. The climate in the study area is mesothermic with cool, moist summers and mild, wet winters. The mean air temperature is $18.7^{\circ} \mathrm{C}$ in summer and $9.6^{\circ} \mathrm{C}$ in winter. The mean annual precipitation ranges between 1200 and $2000 \mathrm{~mm}$ and the heaviest rainfall occurs between September and May. The area is situated $600 \mathrm{~m}$ above sea level. Three representative stands of two mature semi-natural forests (Quercus robur L. and Fagus sylvatica L., hereafter referred to as oak and beech) and a nearby first-rotation and non-mechanised cultivated Pinus radiata D. Don plantation (hereafter referred to as $40 \mathrm{y}$ pine) were sampled for evaluation of soil properties beneath different tree species. The density in the mature stands was approximately 300 trees per ha, although the basal area was larger in the mature pine stand $\left(90 \mathrm{~m}^{2} \mathrm{ha}^{-1}\right)$ than in 
Table I. Soil mineralogical and textural properties (all expressed in $\%$ ) at $0-5 \mathrm{~cm}$ and $5-15 \mathrm{~cm}$ in the soil profile of semi-natural oak and beech stands, and cultivated 40-year-old, 16-year-old and 3-year-old pine stands.

\begin{tabular}{|c|c|c|c|c|c|}
\hline & Oak & Beech & 40 y Pine & 16 y Pine & 3 y Pine \\
\hline \multicolumn{6}{|l|}{$0-5 \mathrm{~cm}$} \\
\hline \multicolumn{6}{|l|}{$\begin{array}{l}\text { Whole soil } \\
\text { mineralogy }\end{array}$} \\
\hline Quartz & 47 & 48 & 42 & 49 & 47 \\
\hline Phyllosillicates & 52 & 51 & 56 & 51 & 53 \\
\hline \multicolumn{6}{|l|}{$\begin{array}{l}\text { Clay }(<2 \mu \mathrm{m}) \\
\text { fraction } \\
\text { mineralogy }\end{array}$} \\
\hline Illite & 30 & 29 & 34 & 44 & 33 \\
\hline Chlorite & 4 & 2 & 5 & 5 & 4 \\
\hline Kaolinite & 16 & 14 & 9 & 8 & 14 \\
\hline $\mathrm{I} / \mathrm{V}$ & 51 & 55 & 52 & 42 & 48 \\
\hline \multicolumn{6}{|l|}{$\begin{array}{l}\text { Whole soil } \\
\text { texture }\end{array}$} \\
\hline Clay & 33 & 29 & 38 & 28 & 32 \\
\hline Silt & 39 & 40 & 40 & 37 & 30 \\
\hline \multirow[t]{3}{*}{ Sand } & 27 & 32 & 22 & 35 & 38 \\
\hline & Clay & Clay & Clay & Clay & Clay \\
\hline & loam & loam & loam & loam & loam \\
\hline \multicolumn{6}{|l|}{$\begin{array}{l}5-15 \mathrm{~cm} \\
\text { Whole soil } \\
\text { mineralogy }\end{array}$} \\
\hline Quartz & 43 & 46 & 43 & 49 & 50 \\
\hline \multicolumn{6}{|l|}{$\begin{array}{l}\text { Clay }(<2 \mu \mathrm{m}) \\
\text { fraction } \\
\text { mineralogy }\end{array}$} \\
\hline Illite & 20 & 28 & 21 & 28 & 25 \\
\hline Chlorite & 2 & $\mathrm{t}$ & 1 & 2 & $\mathrm{t}$ \\
\hline Kaolinite & 16 & 13 & 13 & 10 & 13 \\
\hline $\mathrm{I} / \mathrm{V}$ & 62 & 60 & 64 & 60 & 61 \\
\hline \multicolumn{6}{|l|}{$\begin{array}{l}\text { Whole soil } \\
\text { texture }\end{array}$} \\
\hline Clay & 43 & 37 & 43 & 30 & 34 \\
\hline Silt & 36 & 36 & 38 & 33 & 30 \\
\hline \multirow[t]{3}{*}{ Sand } & 20 & 27 & 20 & 36 & 36 \\
\hline & Clay & Clay & Clay & Clay & Clay \\
\hline & & loam & & loam & loam \\
\hline
\end{tabular}

$\mathrm{t}=$ Trace, $\mathrm{I} / \mathrm{V}=$ illite/vermiculite.

the oak and beech stands (64 and $63 \mathrm{~m}^{2} \mathrm{ha}^{-1}$, respectively). In addition, a chronosequence was sampled from two adjacent clear-cut sites ( 3 and 16 years old) (hereafter referred to as $3 \mathrm{y}$ pine and $16 \mathrm{y}$ pine) to evaluate the effect of mechanised forest operations 3 and $16 \mathrm{y}$ after disturbance. The density of the $16 \mathrm{y}$ pine stand was 1010 trees ha $^{-1}$ and the basal area $18 \mathrm{~m}^{2} \mathrm{ha}^{-1}$. The $3 \mathrm{y}$ pine stand was established by use of a $3 \times 2 \mathrm{~m}$ grid, and at the time of sampling the mean height was $1.2 \mathrm{~m}$. The logging operations in the two disturbed pine plantations included forest harvesting with skidders and site preparation by blading and down-slope ripping. In blading, the residues of the previous plantation and the competing vegetation should be removed without scraping the mineral soil surface. However, sometimes the upper centimetres of soil are also excavated and slash and surface organic material are displaced to small piles down-slope. Down-slope ripping consists of deep ploughing $(\approx 50 \mathrm{~cm})$ following the maximum slope of the stand. All the studied stands faced south and were developed on similar slopes.

\subsection{Sampling and measurements}

Each stand covered an area of approximately 1 ha, and sampling was carried out twice, the first time to obtain composite soil samples and the second time to record data for developing soil strength models. In January 2005 , three randomly selected plots $(10 \mathrm{~m} \times 10 \mathrm{~m})$ were established in each stand, and ten soil samples were systematically collected within each plot by the core method (core diameter $5 \mathrm{~cm}$ ). The samples were divided into $0-5 \mathrm{~cm}$ and $5-15 \mathrm{~cm}$ layers and combined to provide one composite sample per plot and layer. The composite samples were then split into a field-moist portion and a portion for drying. The field-moist portion was sieved to $<2 \mathrm{~mm}$ to remove large woody debris and stones, separated into two replicate samples and frozen at $-20{ }^{\circ} \mathrm{C}$. The other portion was dried at $30{ }^{\circ} \mathrm{C}$ and also sieved to $2<\mathrm{mm}$ and separated into two replicate samples.

Soil strength regression models were developed for each stand from a grid of 34 points. At each point, soil strength was measured with a cone penetrometer (CP 40II, Rimik, Australia), readings were recorded every $1 \mathrm{~cm}$ and the average value of the first 5 readings represented the soil strength in the first $5 \mathrm{~cm}$. In addition, a soil sample was collected for determination of the gravimetric water content. Sampling was carried out twice, once when soils were close to field capacity (May 2005) and the second time when they were close to wilting point (August 2005). In addition, ten soil cores were extracted with stainless steel $\left(100 \mathrm{~cm}^{3}\right)$ cylinders in each stand in order to determine soil bulk density.

\subsection{Laboratory procedures}

Composite samples were analysed for total organic $\mathrm{C}$ and $\mathrm{N}$ in a LECO CNS 2000 autoanalyser (LECO Corporation, MI, USA), soil $\mathrm{pH}-\mathrm{H}_{2} \mathrm{O}$ in a 1:2.5 soil:water suspension and cation exchange capacity (CEC) with ammonium acetate (1 M, pH 7). Extractable aluminium was measured by titration with sodium hydroxide and phenolphthalein, and available phosphorus was analysed by the Olsen method. Water content at $-0.01 \mathrm{MPa}$ (defined as field capacity, $\theta_{\mathrm{fc}}$ ) and water content at $-1.5 \mathrm{MPa}$ (defined as wilting point, $\theta_{\mathrm{wp}}$ ) were also determined in composite samples by the standard tension plate procedure.

Particulate organic matter (POM) was determined by the method of Cambardella and Elliot (1992), as modified by Marriott and Wander (2006).

The microbial community structure was determined by phospholipid fatty acid (PLFA) analysis. Lipids were extracted, fractionated and methylated following the procedure used by Bardgett et al. (1996). Fatty acid methyl esters were analysed by gas chromatography (see Gartzia-Bengoetxea (2008) for details). Bacterial biomass was estimated from the summed concentration of 9 bacterial PLFA,

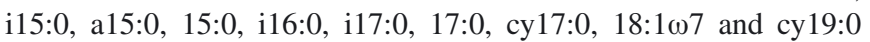

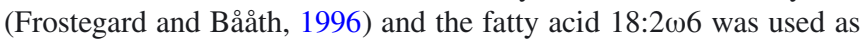
an indicator of fungal biomass (Federle, 1986). The Gram-positive specific fatty acids i15:0, a15:0, i16:0 and i17:0 and the Gram-

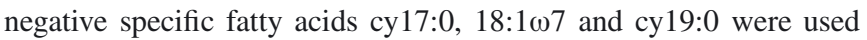
as biomarkers. Total phospholipid fatty acids were compared among 
different types of forest management as nmol g $\mathrm{g}^{-1}$ soil, while PLFAs used as biomarkers were compared on a mole basis (\%) in order to standardise differences in the total amount of soil PLFAs. The diversity of PLFAs was calculated with the Shannon index $H$.

The enzyme assay was performed as a microbial community function by the method of Marx et al. (2001). The enzyme activities assayed were: $\alpha$-1,4-glucosidase, $\beta$-1,4-glucosidase, cellobiohydrolase, $\alpha-1,4$-xylosidase, $\alpha-1,4-\mathrm{N}$-acetylglucosaminidase, acid phosphatase, L-leucine aminopeptidase and L-tyrosine aminopeptidase. All enzyme activities were expressed in $\mathrm{nmol} \mathrm{g}^{-1} \mathrm{~h}^{-1}$.

\subsection{Calculations and statistical analysis}

The least limiting water range (LLWR) was calculated on the basis of critical values for plant growth associated with water potential, soil resistance and air-filled porosity. The values selected for this study were as follows: $0.10 \mathrm{~cm}^{3} \mathrm{~cm}^{-3}$ air-filled porosity (Grable and Siemer, 1968), field capacity at $-0.01 \mathrm{MPa}$ matric potential (Haise et al., 1955), wilting point at $-1.5 \mathrm{MPa}$ matric potential (Richards and Weaver, 1944), and the soil strength restriction limit at 3.0 MPa (Sands et al., 1979).

Water content at field capacity $\left(\theta_{\mathrm{fc}}\right)$ and wilting point $\left(\theta_{\mathrm{wp}}\right)$ were determined in the lab with standard pressure plates. The soil water content identified by the air-filled porosity at $10 \%\left(\theta_{\mathrm{afp}}\right)$ was calculated as $\theta_{\text {sat }}-0.1$, where $\theta_{\text {sat }}=1$-(bulk density/soil particle density) and water content at $3 \mathrm{MPa}\left(\theta_{\mathrm{ss}}\right)$ was determined with regression strength models.

The upper limit of the LLWR is the water content of the driest soil, of either $\theta_{\mathrm{fc}}$ or $\theta_{\mathrm{afp}}$, whereas the lower limit is the water content of the wettest soil, of either $\theta_{\text {wp }}$ or $\theta_{\sigma \sigma}$ (Zou et al., 2000).

One-way analysis of variance (ANOVA) was conducted to compare mean values for each soil depth, and a Student $t$ test to compare the two depths. Factor analyses were performed to reduce the number of variables in extracellular multienzyme activities and PLFA patterns with a correlation matrix. Stepwise discriminant function analysis was used to determine the key soil properties that best predict the forest categories and how good the prediction was. Once the discriminant functions were calculated, a plot of the stretched attribute vectors was calculated by rotating the discriminant functions to redistribute the variance. Correlations between the canonical discriminant functions and each discriminating variable were calculated and multiplied by the univariate $F$ ratio to produce $(x, y)$ coordinates for the endpoint of a vector that has its other endpoint at the origin. Thus, the $F$ value indicates the extent to which each variable makes a significant contribution to discriminating between groups.

These statistical analyses were performed to gain a deeper insight into the data structure. Nevertheless, because of the inherent large variability usually found in the parameters that characterise forest ecosystems and also the lack of stand replicates, statistical analyses were used to reveal trends in changes among the studied stands, rather than to make specific conclusions about the effects of species change or mechanical operations on soil properties.

\section{RESULTS}

\subsection{Chemical soil properties}

Soil organic $\mathrm{C}$ contents in the upper soil layer were similar in all stands except the 3 y pine stand (Tab. II); concentrations of nitrogen, available phosphorus and potassium, and cation exchange capacity (CEC) were also significantly lower in the latter stand. There was a significant decrease with depth in all elements associated with soil organic matter, such as total soil nitrogen, soil phosphorus and CEC. In contrast, soil $\mathrm{pH}$ increased with depth and was significantly higher in oak stands, but was almost always below 5 (Tab. II).

However, although the quantity of soil organic matter did not differ among mature stands, the quality of the soil organic matter differed significantly with tree species. The contents of labile $\mathrm{C}$ and particulate organic matter (POM) were higher in oak and beech stands than in the $40 \mathrm{y}$ pine stands. Conversely, a reduction in labile $\mathrm{C}$ with depth was observed in all stands except in the mature pine stand (Tab. III).

\subsection{Biological soil properties}

\subsubsection{Microbial community structure}

Microbial biomass, considered as total amounts of PLFA, differed with intensive preparation of pine stands. The microbial biomass was similar in mature stands of both native and exotic species. In contrast, microbial biomass was highest in the $16 \mathrm{y}$ pine stand and lowest in the $3 \mathrm{y}$ pine stand (Tab. III).

The soil microbial community was dominated by bacterial biomass, which accounted for $52-56 \%$ of the total PLFA and as in microbial biomass, the only significant differences observed were between the $16 \mathrm{y}$ and $3 \mathrm{y}$ pine stands. In contrast, there were differences among tree species in fungal biomass; fungal biomass content was significantly higher in the $40 \mathrm{y}$ pine than in oak and beech stands. Furthermore, fungal biomass was significantly lower in recently established stands than in older pine stands (Tab. III).

A shift in bacterial community was detected on the basis of PLFA biomarkers. Gram-positive bacteria (i15:0, a15:0, i16:0 and i17:0) made up a large component of the bacterial community in the upper horizon of the $3 \mathrm{y}$ pine stand $(P<0.05)$, while Gram-negative bacteria $(16: 1 \omega 7,18: 1 \omega 7$, cy17:0 and cy 19:0) were less abundant $(P<0.05)$ (Tab. III). The ratio between Gram-positive bacteria and Gram-negative bacteria was significantly higher in the $3 \mathrm{y}$ pine stand $(P<0.0001)$ than in the other stands.

Microbial biomass in 16 and 3 y pine stands was significantly lower in the lower soil layer than in the surface layer, but microbial biomass did not differ with depth in mature stands. The soil microbial community was also dominated at depth by 18:1 $107,18: 1 \omega 9 \mathrm{c}$ and 16:0. The ratio between Gram-positive bacteria and Gram-negative bacteria increased with depth in all stands except the 3 y pine stand (Tab. III). There was also a clear reduction in the fungal to bacterial PLFA ratio from the surface to the deeper soil horizon $(P<0.05)$ (data not shown). The PLFA diversity and species richness, as estimated by the Shannon diversity index, was lower in oak stand than in beech and pine stands at $0-5 \mathrm{~cm}$ soil depth $(P<0.05)$ (Tab. III). 
Table II. Soil chemical properties at $0-5 \mathrm{~cm}$ and $5-15 \mathrm{~cm}$ in the soil profile of semi-natural oak and beech stands, and cultivated 40-year-old, 16-year-old and 3-year-old pine stands.

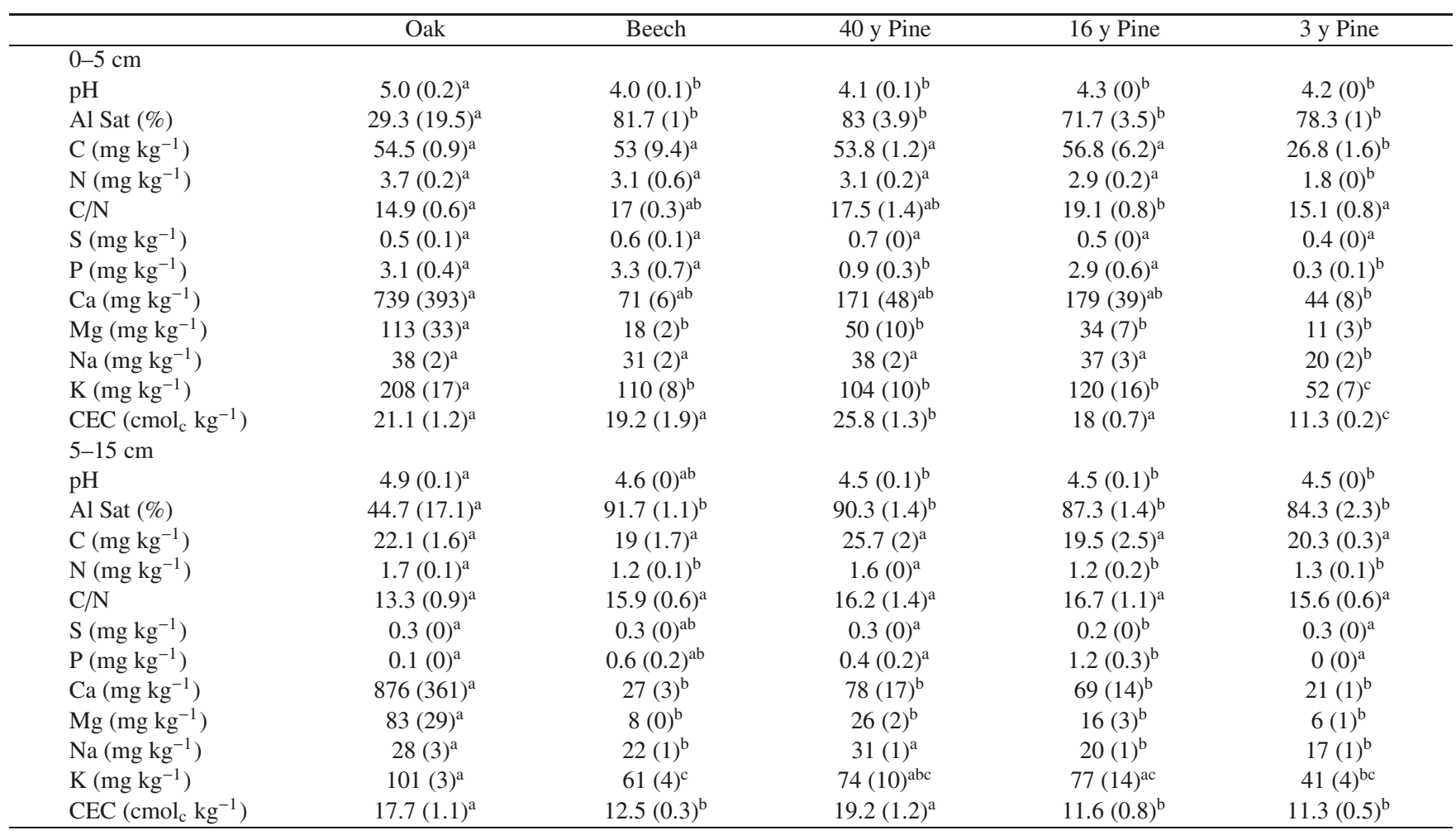

Values are the means of three replicates, with standard errors in parentheses. Different letters in the same row indicate significant differences at $P<0.05$.

Table III. Particulate organic matter ( $\mathrm{mg} \mathrm{C} \mathrm{g}^{-1}$ soil), microbial, bacterial and fungal biomass (nmol PLFA g ${ }^{-1}$ soil), Gram-negative (Gram-) and Gram-positive (Gram+) biomarkers (\%mole PLFA) and Shannon diversity index $H$ at $0-5 \mathrm{~cm}$ and 5-15 cm in the soil profile of semi-natural oak and beech stands, and cultivated 40-year-old, 16-year-old and 3-year-old pine stands.

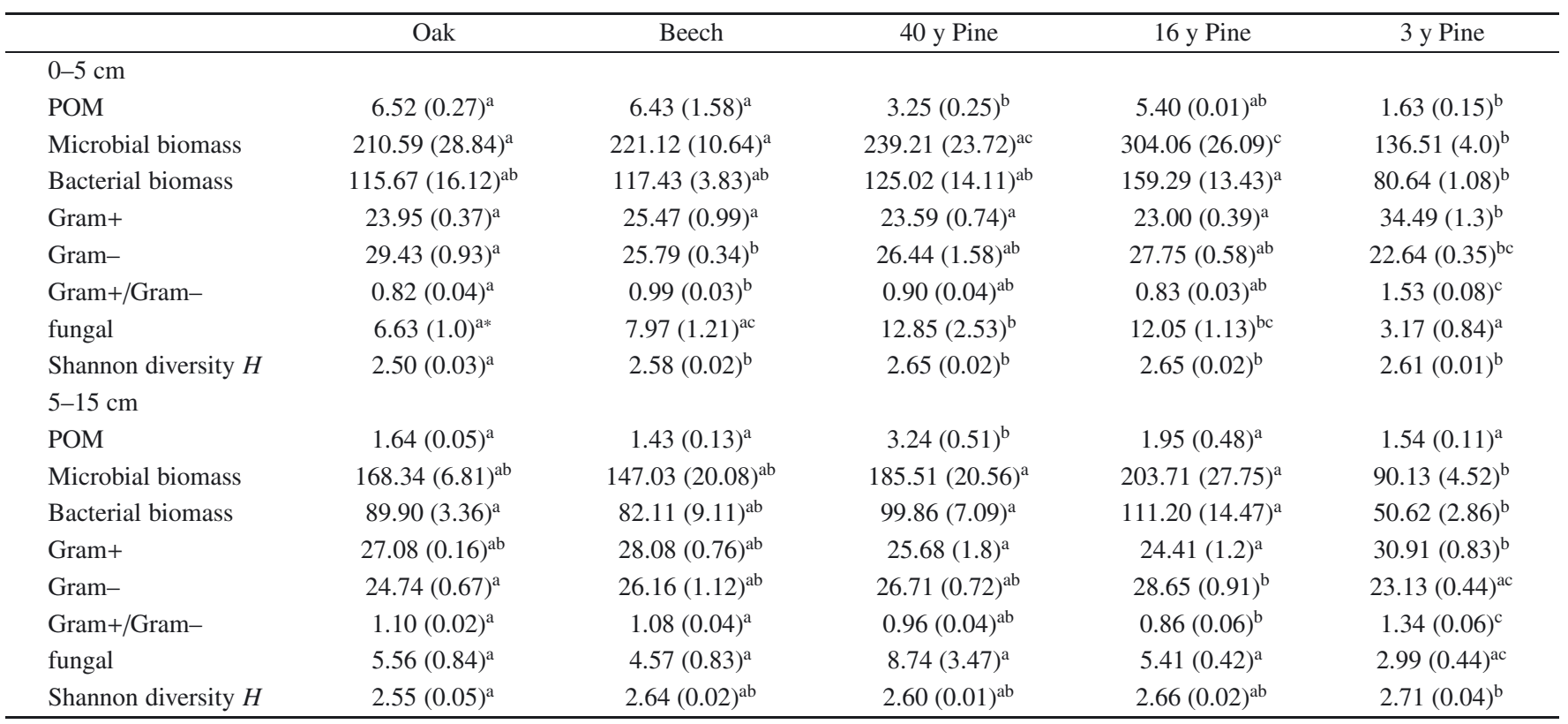

* Significance level, $P<0.1$. Values are the means of three replicates, with standard errors in parentheses. Different letters in the same row indicate significant differences at $P<0.05$. 
Table IV. Extracellular enzyme activities in nmol $\mathrm{g} \mathrm{soil}^{-1} \mathrm{~h}^{-1}$ at $0-5 \mathrm{~cm}$ and $5-15 \mathrm{~cm}$ in the soil profile of semi-natural oak and beech stands, and cultivated 40-year-old, 16-year-old and 3-year-old pine stands.

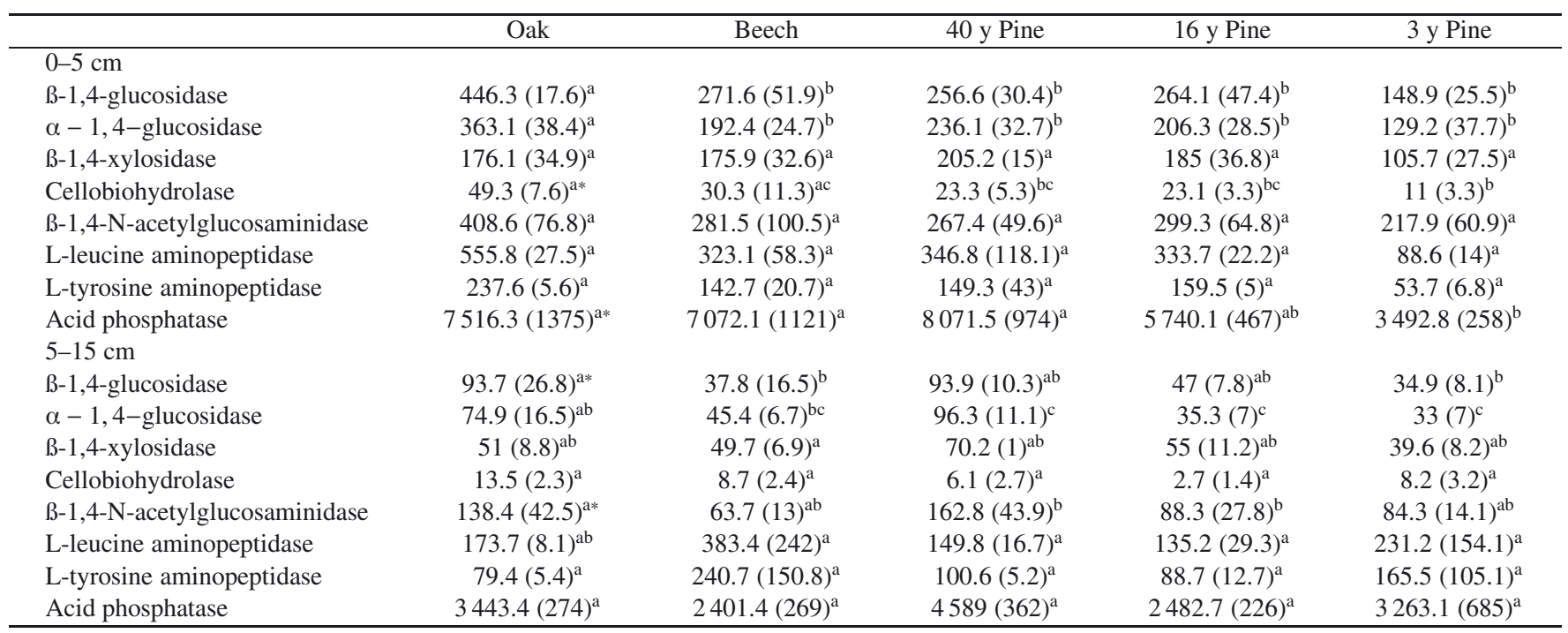

* Significance level, $P<0.1$. Values are the means of three replicates, with standard errors in parentheses. Different letters in the same row indicate significant difference at $P<0.05$.

\subsubsection{Microbial community function}

Extracellular enzyme activities involved in $\mathrm{C}, \mathrm{N}, \mathrm{P}$ and $\mathrm{S}$ cycles decreased within the soil profile in all sites (Tab. IV). The oak ecosystem was characterised by higher $\beta$-glucosidase and $\alpha$-glucosidase activities in the upper soil layer $(0-5 \mathrm{~cm})$ than in the other sites $(P<0.05)$. Although the differences between most individual extracellular enzyme activities were not statistically significant, there was a $32-74 \%$ reduction in all enzyme activities in the 3 y pine plantation, relative to the average activity across other ecosystems.

Phosphatase activity was extremely high in all ecosystems in comparison with the values reported in previous studies (Hasset and Zak, 2005; Sinsabaugh et al., 2003). Mean phosphatase activity was $7.5 \mu \mathrm{mol} \mathrm{h} \mathrm{h}^{-1} \mathrm{~g}^{-1}$ for the oak ecosystem, $7.1 \mu \mathrm{mol} \mathrm{h}^{-1} \mathrm{~g}^{-1}$ for the beech forest, and 8.1, 5.7 and $3.5 \mu \mathrm{mol} \mathrm{h} \mathrm{h}^{-1} \mathrm{~g}^{-1}$, respectively, for the $40 \mathrm{y}, 16 \mathrm{y}$ and $3 \mathrm{y}$ pine stands. The acid phosphatase activity was significantly higher $(P<0.1)$ in mature stands than in the other stands.

Data obtained from the upper soil by a multienzyme assay with MUB substrates were used for principal component analyses and the initial eight enzyme variables were reduced to three factors. PCA1 explained $50 \%$ of the variance and was associated with polysaccharide decomposition and strongly correlated with the activities of three enzymes involved in the production of glycosides and cellobiohydrolase. PCA2 explained $20 \%$ of the variance and was associated with the $\mathrm{N}$ cycle (amino peptidases). PCA3 explained 18\% of the variance and was related to mineralisation of organic phosphorus. Xylosidase activity, which causes degradation of hemicellulose, was correlated with PCA3. At the lower soil depth, PCA1 and PCA2 explained $48 \%$ and $26 \%$ of the total vari-
Table V. Critical points for determination of least limiting water range (LLWR) for root growth. $\rho_{\mathrm{b}}$, bulk density $\left(\mathrm{g} / \mathrm{cm}^{3}\right), \theta_{\mathrm{fc}}$, water content at field capacity $(-0.01 \mathrm{MPa}), \theta_{\text {wp }}$, water content at wilting point $(-1.5 \mathrm{MPa}), \theta_{\mathrm{ss}}$, water content at $3 \mathrm{MPa}$ soil strength, $\theta_{\mathrm{afp}}$, water content at $10 \%$ air-filled porosity and AWC, available water capacity. Values in italics represent the upper and lower limits of LLWR.

\begin{tabular}{lccccc}
\hline & Oak & Beech & 40 y Pine & 16 y Pine & 3 y Pine \\
\hline$\rho_{\mathrm{b}}$ & 1.20 & 1.29 & 1.09 & 1.15 & 1.35 \\
$\theta_{\mathrm{fc}}$ & 0.40 & 0.36 & 0.39 & 0.31 & 0.24 \\
$\theta_{\mathrm{wp}}$ & 0.18 & 0.15 & 0.20 & 0.15 & 0.10 \\
$\theta_{\mathrm{ss}}$ & 0.22 & 0.20 & 0.22 & 0.17 & 0.19 \\
$\theta_{\text {afp }}$ & 0.44 & 0.41 & 0.49 & 0.46 & 0.38 \\
LLWR & 0.19 & 0.16 & 0.18 & 0.14 & 0.05 \\
AWC & 0.28 & 0.21 & 0.19 & 0.16 & 0.14 \\
\hline
\end{tabular}

ance, respectively. PCA1 was associated with $\mathrm{C}$ and $\mathrm{P}$ cycles and PCA2 with the $\mathrm{N}$ cycle; however, it was not possible to distinguish the different types of forest management.

\subsection{Physical soil properties}

Soil moisture content at sampling decreased significantly from $0-5 \mathrm{~cm}$ to $5-15 \mathrm{~cm}$ depth in all stands except the $3 \mathrm{y}$ pine stand, in which there was no difference in moisture level between the two horizons; the values were very close to those observed in the deeper horizon in the other stands. Bulk densities from $0-5 \mathrm{~cm}$ depth ranged from $1.09 \mathrm{~g} \mathrm{~cm}^{-3}$ in the $40 \mathrm{y}$ pine stand to $1.35 \mathrm{~g} \mathrm{~cm}^{-3}$ in the $3 \mathrm{y}$ pine stand and soil water content at field capacity decreased with increasing bulk density (Tab. V). 
Soil water content at field capacity ranged from $0.24 \mathrm{~cm}^{3} \mathrm{~cm}^{-3}$ in the pine stand (3-year-old) to $0.40 \mathrm{~cm}^{3} \mathrm{~cm}^{-3}$ in the oak stand, and water contents at field capacity were higher in all mature stands than in younger stands ( 3 and $16 \mathrm{y})$. In addition, soil water content at wilting point ranged from $0.10 \mathrm{~cm}^{3} \mathrm{~cm}^{-3}$ to $0.20 \mathrm{~cm}^{3} \mathrm{~cm}^{-3}$ and was also lowest in the 3 y pine stand (Tab. V).

The relationship between soil strength and water content was established in each plot over the range between close-tofield capacity and wilting point. Soil strength increased as soil water content decreased in all plots. Soil strength curves were fitted to a logarithmic model (Zou et al., 2000) (Fig. 1). The highest estimate of $a$ corresponded to the oak stand, whereas the estimates for the beech, and the $40 \mathrm{y}$ and $16 \mathrm{y}$ pine stands were very similar, and the lowest estimate was again for the 3 y pine stand. However, water content at 3 MPas was higher in all mature stands than in younger stands.

The upper limiting factor of LLWR was always defined by water content at field capacity, while the lower limiting factor was characterised by water content at $3 \mathrm{MPa}$ soil strength. The least limiting water range followed the order: oak $>$ pine $(40 \mathrm{y})>$ beech $>$ pine $(16 \mathrm{y})>$ pine $(3 \mathrm{y})(\mathrm{Tab} . \mathrm{V})$. In all cases, LLWR was lower than the traditional available water capacity (AWC, the difference between field capacity and wilting point), indicating that less water was available for plant growth than that determined by AWC. The LLWR was 22 and $34 \%$ lower than AWC in the oak and beech stands, respectively, 10 and $16 \%$ lower in the $40 \mathrm{y}$ and $16 \mathrm{y}$ pine stands, respectively, and $300 \%$ lower in the $3 \mathrm{y}$ pine stand. The results showed that a $15 \%$ increase in bulk density can lead to a $236 \%$ reduction in LLWR.

\subsection{Identifying key soil properties}

In order to differentiate among stands and determine which indicators gave rise to site discrimination patterns, discriminant function analysis was used. Discriminant analysis predicts group membership based on a linear combination of potential variables. Discriminant analyses were performed on the basis of physical, chemical and biological properties of the topsoil. The analysis considered a total of 29 potential indicators (13 chemical, 12 biological and 4 physical). Although $94 \%$ of the total variance was explained by chemical parameters alone (parameters shown in Tab. I + POM), only $53 \%$ of cross-validated grouped cases were classified correctly (Fig. 2). Physical parameters alone (bulk density, water contents at field capacity and wilting point, and water contents at $10 \%$ air-filled porosity) grouped $73 \%$ of cross-validated grouped cases correctly. Discriminant analysis for biological parameters was based on microbial, bacterial and fungal biomass, Gram-positive and Gram-negative bacteria and the Gram-positive/Gram-negative ratio, and the reduced factors from extracellular enzyme activities (3 PCA factors explaining $88 \%$ of the total variance) and PLFAs (3 PCA factors explaining $80 \%$ of the total variance). Biological parameters grouped $53 \%$ of cross-validated grouped cases correctly and the discrimination corresponded to PCA1 and PCA3 from multivariate analysis of enzyme activities, PCA3 from multivariate

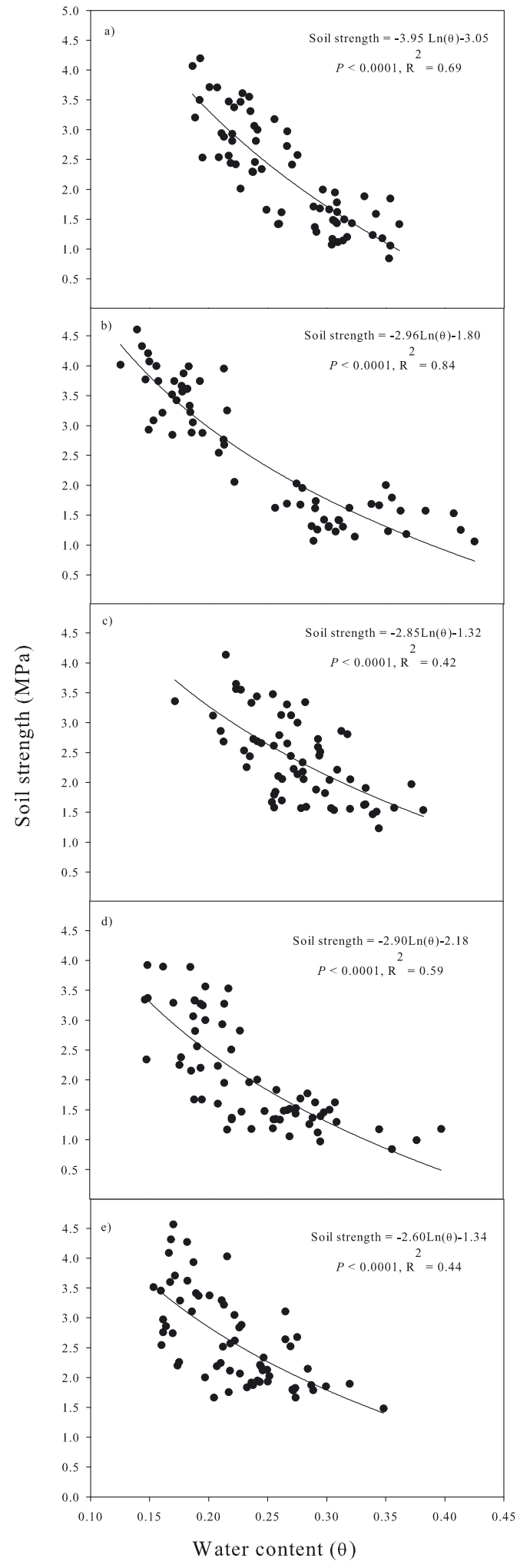

Figure 1. Soil strength regression models developed for each stand from data corresponding to a grid of 34 points in the range between close-to-field capacity and wilting point in the $0-5 \mathrm{~cm}$ soil layer. (a) oak, (b) beech, (c) pine (40-year-old), (d) pine (16-year-old) and (e) pine (3-year-old). 

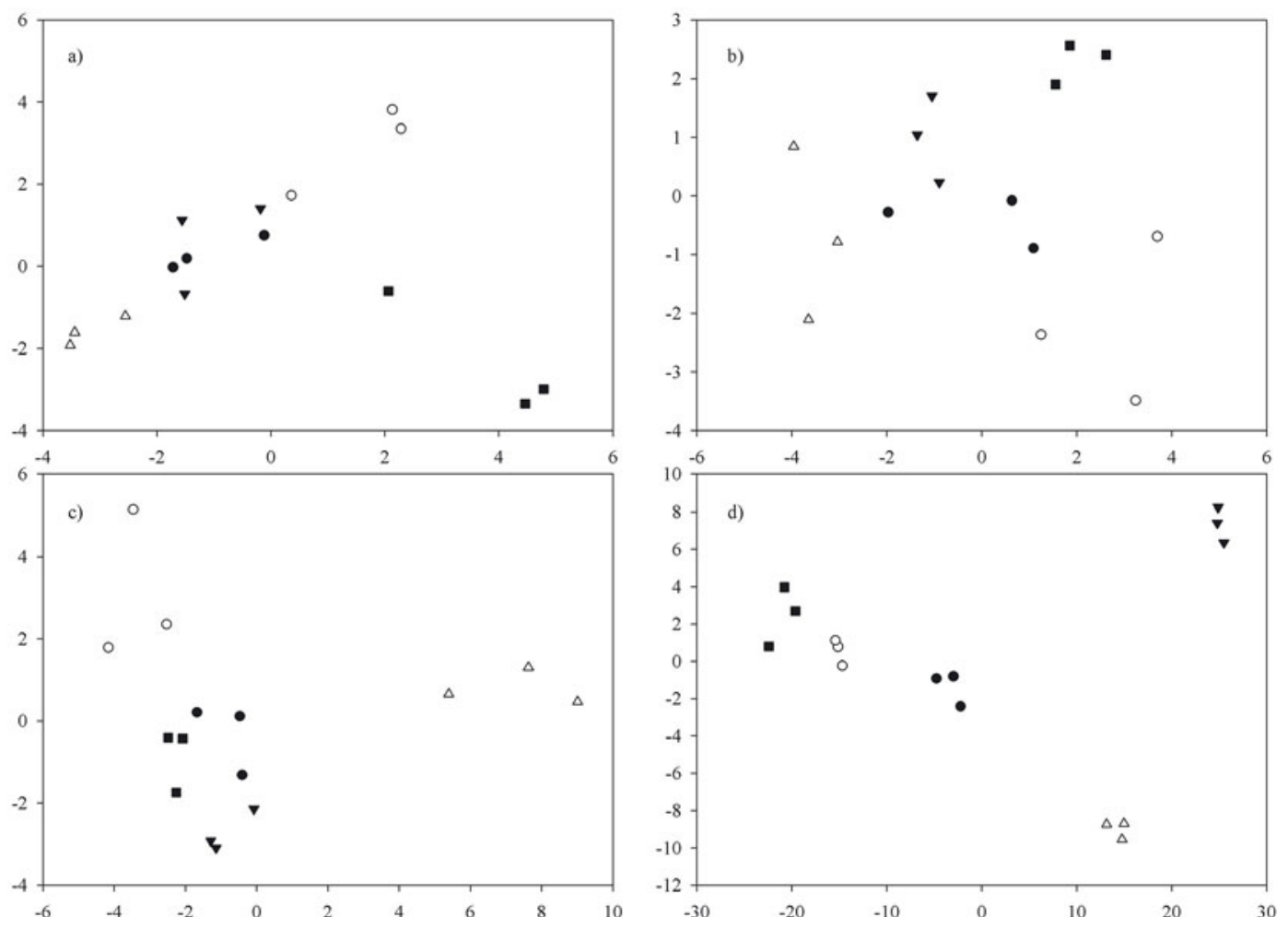

Figure 2. Discriminant analysis for the $0-5 \mathrm{~cm}$ soil layer, based on (a) soil chemical parameters, (b) physical parameters, (c) biological parameters and (d) soil physical, chemical and biological parameters. Stands are represented as follows: oak (o), beech (•), 40-year-old pine $(\mathbf{\square})$, 16-year-old pine $(\mathbf{\nabla})$ and 3-year-old pine $(\Delta)$.

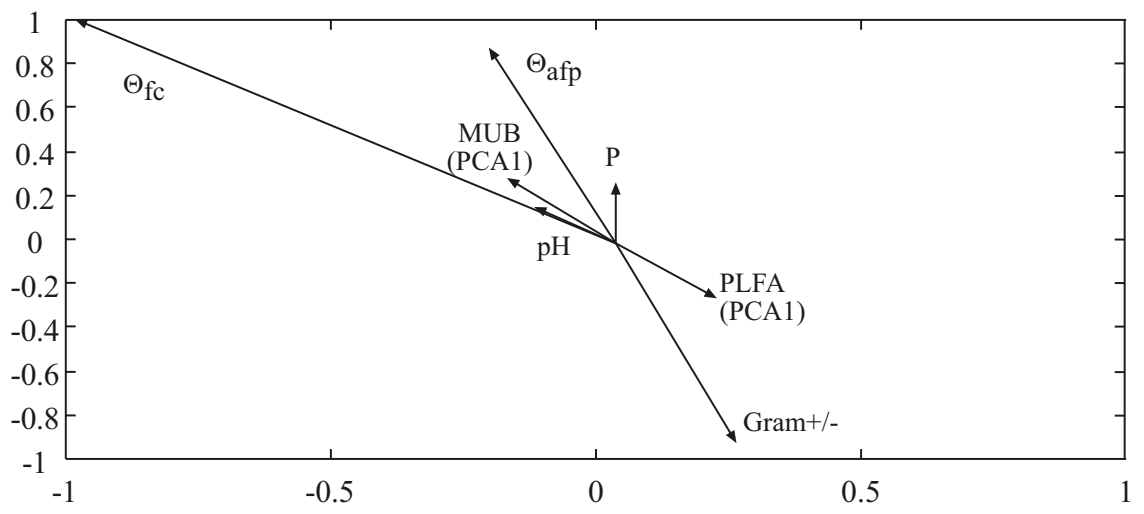

Figure 3. Attribute vector plot calculated by rotating the discriminant functions of soil chemical, physical and biological parameters in the $0-5 \mathrm{~cm}$ soil layer.

analysis of PLFAs and the Gram-positive/Gram-negative ratio. PCA1 and PCA3 from multivariate analysis of enzyme activities were related to enzymes involved in $\mathrm{C}$ and $\mathrm{P}$ cycles and PCA3 from multivariate analysis of individual PLFAs was related to fungal biomarkers.

The model based on a total of 29 properties was highly accurate, and correctly classified all stands, with $90 \%$ of stands correctly classified in the cross-validation. A classification error in cross-validation occurred among oak and mature pine stands, and a third of oak stands were classified as pine ( $40 \mathrm{y}$ ) and vice versa. This may be because the $40 \mathrm{y}$ pine stand shares some characteristics with the oak stand.

The relationships between individual soil properties or discriminating variables and forests were revealed by the stretched attribute vectors (Fig. 3). Of the 29 variables considered, the 7 that represent most of the information correspond to soil physical, chemical and biological properties, which suggests that these properties may be useful in differentiating 
forests that differ in species and intensity of mechanisation. Water contents at field capacity and $10 \%$ air-filled porosity, parameters related to soil organic matter and compaction, were higher in mature stands than in younger mechanised stands. Such differences may lead to differences in the structure of the soil microbial community.

\section{DISCUSSION}

\subsection{Effect of depth on soil properties}

Differences among species may be caused by differences in the amount and quality of litter and by differences in processes taking place on the forest floor (Hagen-Thorn et al., 2004). Moreover, differences between logged (harvest, site preparation and ripping) and unlogged pine forests may be caused by changes in the quantity and quality of litter as well as by alterations in the physical structure of the upper soil layer (Hassett and Zak, 2005). In the present study, differences in all soil properties were more pronounced in the upper layer of the mineral soil.

The lack of differences in the lower layer of forest soils may be due to similar soil organic matter contents in all stands and very slight differences in soil organic matter quality, and consequently, similar biological activity of the microbial community. An increase in the abundance of Gram-positive bacterial PLFA and lower extracellular enzymes activities with depth may result from changes in water potential and a reduction in organic matter within the soil profile (Hasett and Zak, 2005; Waldrop et al., 2003). This pattern therefore has an important functional role in nutrient cycling dynamics and implications for nutrient management in forest plantations.

\subsection{Effect of tree species on soil properties}

The results revealed that organic matter dynamics in pine forests and oak and beech forests may differ because of the greater fungal biomass and lower POM in pine forests. Hackl et al. (2005) also found higher concentrations of fungal fatty acids in pine forests than in beech or oak forests and suggested that was because fungi were presumably more efficient than bacteria at decomposing pine litter. Pine litter contains large amounts of tannins and lignins and it is well known that fungi are the main degraders of lignin (Dix and Webster, 1995). Part of the fungal biomass measured as fungal PLFA in pine forest soils may be derived from ectomycorrhizal fungi (Olsson, 1999), which are known to be dominant colonisers of the Pinaceae family (Smith and Read, 1997). Furthermore, Salas et al. (2003) found a correspondence between fungal colonisation and POM-P, which indicated that the dynamics of this macroorganic matter may significantly influence $\mathrm{P}$ cycling and that the P contained in this OM pool may have a significant effect on $\mathrm{P}$ availability. It may be interesting to focus further studies on the dynamics of POM-P and fungal biomass, while considering that the availability of $\mathrm{P}$ is the main factor limiting tree growth, because of the strongly acidic nature of the soils in northern Spain (Sanchez-Rodríguez et al., 2002). Martínez de Arano (2001) reported P-Olsen levels below $5 \mathrm{mg} \mathrm{kg}^{-1}$ and $\mathrm{P}-\mathrm{HCl}$ levels below $150 \mathrm{mg} \mathrm{kg}^{-1}$ for $70 \%$ of forests studied in the Basque Country, probably because of (i) the low solubility of phosphate at the low $\mathrm{pH}$ values of the soils under study, and (ii) phosphate sorption onto reactive surfaces of variable charge compounds (e.g., $\mathrm{Fe}$ and $\mathrm{Al}$ oxyhydroxides) (Lajtha and Schlesinger, 1988). Such deficiencies may explain the very high phosphatase activities observed in the present study, associated with the negative relationship between phosphatase activity and total $\mathrm{P}$ in different forests (Olander and Vitousek, 2000, Waldrop et al. 2003). Since phosphatase activity is related to soil organic matter (Santruckova et al., 2004), the soil microbial community appears to invest much energy in the production of this enzyme and in acquisition of inorganic P for microbial growth (Clarholm, 1993).

Bulk densities were significantly higher in the oak and beech stands than in the mature pine stand. This may be attributed to a combination of higher grazing intensity in seminatural stands and higher compacting forces produced by the roots themselves (Greacen and Sands, 1980); however, the differences in bulk densities were not reflected in water contents at field capacity, wilting point, $10 \%$ air-filled porosity or soil strength at $3 \mathrm{Mpa}$. Furthermore, LLWR -defined as an index of soil quality for plant growth- was very similar in all mature stands and higher than the values reported by Leao et al. (2006) for native Cerrado forest in Brazil.

\subsection{Logging effect on soil properties}

The effects of removal of soil organic matter and alteration of soil physical structure induced by logging were very pronounced in the youngest Pinus radiata stand, at 3 y after establishment. Total $\mathrm{C}$ and some chemical parameters related to SOM, such as CEC, were significantly lower in this stand than in the other stands. The observed decrease in microbial biomass was consistent with the removal of organic matter (Hasset and Zak, 2005), and it is known that increased intensity of physical disturbance causes a decrease in fungal biomass (Gattinger et al., 2002). The bacterial community also shifted in the recently logged stand and there was an increase in abundance of Gram-positive bacterial PLFA with a concomitant decrease in Gram-negative bacterial PLFA. The present results are consistent with those of previous studies carried out in different ecosystems (Margesin et al., 2003; 2007), and can be explained by differences in microbial populations in terms of patterns of growth and reproduction. Grampositive soil bacteria are able to use more complex carbon sources, such as mature SOM, and survive in resource-limited ecosystems ( $K$ strategist); however, Gram-negative bacteria rely on recent, easily degradable carbon sources (plants) and grow under substrate-rich conditions ( $r$ strategists). Dale et al. (2008) also reported higher Gram-positive PLFA indices in pine forests with moderate- and heavy-intensity military use 
in Georgia, USA, and Siira-Pietikainen et al. (2001) concluded that the PLFA pattern was a sensitive indicator for identifying stress conditions induced by harvesting and mechanical site preparation in microbial communities, resulting from harvesting of spruce forests in Finland.

Soil physical properties were significantly altered by logging operations, even $16 \mathrm{y}$ after plantation establishment. Compaction produced by vehicles used in the forest operations was still evident in the $16 \mathrm{y}$ pine stand in comparison with the mature unlogged pine stand. Changes in soil structure are reflected in water content and gas diffusion, and therefore in plant growth (da Silva and Kay, 2004). As expected, water content at $10 \%$ air-filled porosity decreased with increasing bulk density, and water content at field capacity also decreased with decreasing soil organic matter.

The results obtained show that LLWR was more effective than AWC in terms of reflecting changes in soil strength, pore size ditribution and water retention in a meaningful single parameter. Similar values of LLWR to those obtained for pine ( 3 y) were reported for grazed pasture (Leao et al., 2006) and even lower values in soils under wheel tracks (Chan et al., 2006). Soils with a narrow LLWR are vulnerable to the effects of both drought and heavy rainfall (da Silva and Kay, 1997b), and Benjamin et al. (2003) found that narrow LLWR may reduce the potential of a soil to support plant growth. The least limiting water range may therefore be a sensitive indicator of soil quality for plant growth and protection of water.

\subsection{Identifying key soil properties}

The ocurrence of singularities and multi-colinearities when all the indicators were used in the analysis were solved by use of the stepwise discriminant method (Stevens, 2002). Moreover, when groups are defined a priori (as in this study), stepwise discriminant analysis is better than another commonly used method to describe multivariate data, namely Principal Component Analysis (PCA) (Tabachnik and Fidell, 2001). The seven soil properties selected by discriminant function analysis represent the range of ecological indicator types that were surveyed in the present study: soil physical, chemical and biological properties. Water content at field capacity was consistently correlated with soil organic matter, and water content at $10 \%$ air-filled porosity with bulk density. The stretched attribute vector analysis revealed that these physical parameters correspond to mature stands, which reflects the influence of logging operations on both soil organic matter and soil physical structure. A shift in soil microbial community was apparent in the recently logged pine stand, and thus the ratio of Grampositive/Gram-negative bacteria appears to be a promising microbial indicator for detecting changes caused by forest management. The presence of phosphorus in discriminant function analysis reflects nutritional stress in the forest ecosystems. The results suggest that an adequate minimum dataset for evaluating the sustainability of forest management should reflect this diversity.

\section{CONCLUSIONS}

Development of sustainable forestry practices and credible certification systems relies on continuous monitoring of indicators. The National Forest Inventory (NFI), which is the only monitoring programme existing in Spain, provides information on the development of aboveground forest resources. However, assessment of the sustainability of forest management requires soil-based sustainability indicators because forestry affects soil systems. The conclusions reached in the present study could be used as a starting point for planning soil monitoring programmes.

Since the values of many soil properties, especially soil biological properties, decreased within the soil profile, the upper $5 \mathrm{~cm}$ of the mineral horizon may be recommended as the most appropriate for evaluating changes related to forest management. Discriminant function analysis revealed that a diverse set of ecological indicators may be needed to assess the sustainability of forest management. Parameters such as the ratio of Gram-positive/Gram-negative bacteria, water content at field capacity and concentration of phosphorus may be responsive to logging operations. LLWR may be effective for reflecting changes in soil strength, pore size distribution and water retention in a meaningful single parameter. PLFA fingerprints (i.e. fungal biomarkers) were also able to detect more subtle shifts in soil function, probably due to changes in litter quality and quantity.

All of these properties may be valuable and complementary tools that provide insights into soil ecosystem processes. However, good indicators of forest sustainability should relate to a benchmark or target that defines a sustainable level, and further studies are needed in temperate forest ecosystems to assess natural boundaries of variation and the resilience of soil properties.

Acknowledgements: Funding for this study was provided by the European Union ERDF-INTERREG IIIB Atlantic Area the Department of Agriculture, Fisheries and Food of the Basque Country, and INIA, Instituto Nacional de Investigación y Technoligía Agracia y Alimentarion SUM2006-0013.00.00. We thank Dr. Javier Arostegui for helping with mineralogical analyses and Sabine Rudolph for technical assistance with PLFA analysis. We also thank Dr. Christine Francis for revising the English of the manuscript.

\section{REFERENCES}

Bardgett R.D., Hobbs P.J., and Frostegård Å., 1996. Changes in fungal: bacterial biomass ratios following reductions in the intensity of management on an upland grassland. Biol. Fertil. Soils 22: 261-264.

Bauhus J, Khanna P.K., Hopmans P., and Weston C., 2002. Is soil carbon a useful indicator of sustainable forest soil management?-a case study from native eucalypt forests of south-eastern Australia. For. Ecol. Manage. 171: 59-74.

Benjamin J.G., Nielsen D.C., and Vigil M.F., 2003. Quantifying effects of soil conditions on plant growth and crop production. Geoderma 116: 137-148.

Cambardella C.A. and Elliot E.T., 1992. Particulate soil organic matter changes across a grassland cultivation sequence. Soil Sci. Soc. Am. J. 56: 777-783. 
Chan K.Y., Oates A., Swan A.D., Hayes R.C., Dear B.S., and Peoples M.B., 2006. Agronomic consequences of tractor wheel compaction on a clay soil. Soil Tillage Res. 89: 13-21.

Clarholm M., 1993. Microbial biomass P, labile P, and acid phosphatase activity in the humus layer of a spruce forest, after repeated additions of fertilizers. Biol. Fertil. Soils 16: 287-292.

Dale V.H., Peacock A.D., Garten Jr. C.T., Sobek E., and Wolfe A.K., 2008. Selecting indicators of soil, microbial, and plant conditions to understand ecological changes in Georgia pine forests. Ecol. Indic. 8: 818-827.

Da Silva A.P. and Kay B.D., 1997. Effect of soil water content on the variation in the least limiting water range. Soil Sci. Soc. Am. J. 58: $1775-1781$.

Da Silva A.P. and Kay B.D., 2004. Linking process capability analysis and least limiting water range for assessing soil physical quality. Soil Tillage Res. 79: 167-174.

Dix N.J. and Webster J., 1995. Fungal Ecology. Chapman \& Hall, London.

Doran J.W., 2002. Soil health and global sustainability: Translating science into practice. Agric. Ecosyst. Environ. 88: 119-122.

Doran J.W. and Parkin T.B., 1994. Defining and assessing soil quality. SSSA Special Publication, Madison, Wisconsin, EEUU 35: 3-21.

Federle T.W., 1986. Microbial distribution in soil- new techniques. Perspectives in microbial ecology. Slovene Society for Microbiology, Ljubljana, Slovenia , 493-498.

Frostegard A. and Bååth E., 1996. The use of phospholipid fatty acid analysis to estimate bacterial and fungal biomass in soil. Biol. Fertil. Soils 22: 59-65.

Gartzia-Bengoetxea N., 2008. Structure and dynamics of soil organic matter in temperate forest ecosystems: from case studies to landscape level. Ph.D. thesis, NEIKER-Tecnalia. Basque Institute for Agricultural Research and Development, Basque Country, 213 p.

Gattinger A., Ruser R., Schloter M., and Munch J.C., 2002. Microbial community structure varies in different soil zones in a potato field. J. Plant Nutr. Soil Sci. 165: 421-428.

Godefroid S., Monbaliu D., Massant W., Van der Aa B., De Vos B., Quivy V., and Koedam N., 2007. Effects of soil mechanical treatments combined with bramble and bracken control on the restoration of degraded understory in an ancient beech forest. Ann. For. Sci. 64: $321-331$.

Grable A.R. and Siemer E.G., 1968. Effects of bulk density, aggregate size, and soil water suction on oxygen diffusion, redox potential elongation of corn roots. Soil Sci. Soc. Am. J. 32: 180-186.

Greacen E.L. and Sands R., 1980. Compaction of forest soils: a review. Aust. J. Soil Res. 18: 163-188.

Hackl E., Pfeffer M., Donat C., Bachmann G., and ZechmeisterBoltenstern S., 2005. Composition of the microbial communities in the mineral soil under different types of natural forest. Soil Biol. Biochem. 37: 661-671.

Haise H.R., Haas H.J., and Jensen L.R., 1955. Soil moisture studies of some great plain soils. II. Field capacity as related to $1 / 3$ atmosphere percentage, and "minimum point" as related to 15- and 26atmosphere percentage. Soil Sci. Soc. Am. J. 34: 20-25.

Hagen-Thorn A., Callesen I., Armolaitis K., and Nihlgård B., 2004. The impact of six European tree species on the chemistry of mineral topsoil in forest plantations on former agricultural land. For. Ecol. Manage. 195: 373-384.
Hassett J.E. and Zak D.R., 2005. Aspen harvest intensity decreases microbial biomass, extracellular enzyme activity, and soil nitrogen cycling. Soil Sci. Soc. Am. J. 69: 227-235.

Lajtha K. and Schlesinger W.H., 1988. The biogeochemistry of phosphorus cycling and phosphorus availability along a desert soil chronosequence. Ecology 69: 24-39.

Leão T.P., da Silva A.P., Macedo M.C.M., Imhoff S., and Euclides V.P.B., 2006. Least limiting water range: A potential indicator of changes in near-surface soil physical quality after the conversion of Brazilian Savanna into pasture. Soil Tillage Res. 88: 279-285.

Leckie S.E., Prescott C.E., and Grayston S.J., 2004. Forest floor microbial community response to tree species and fertilization of regenerating coniferous forests. Can. J. For. Res. 34: 1426-1435.

Margesin R., Labbé D., Schinner F., Greer C., and Whyte L., 2003. Characterization of hydrocarbon-degrading microbial populations in contaminated and pristine alpine soils. Appl. Environ. Microbiol. 69: 3085-3092.

Margesin R., Hämmerle M., and Tscherko D., 2007. Microbial activity and community composition during bioremediation of diesel-oilcontaminated soil: effects of hydrocarbon concentration, fertilizers and incubation time. Microb. Ecol. 53: 259-269.

Mariani L., Chang S.X., and Kabzems R., 2006. Effects of tree harvesting, forest floor removal, and compaction on soil microbial biomass, microbial respiration and $\mathrm{N}$ availability in a boreal aspen forest in British Columbia. Soil Biol. Biochem. 38: 1734-1744.

Marriott E.E. and Wander M.M., 2006. Total and labile soil organic matter in organic and conventional farming systems. Soil Sci. Soc. Am. J. 70: 950-959.

Martínez de Arano I., 2001. Estado nutritivo y recomendaciones de fertilización para Pinus radiata. Euskadi Forestal 61: 47-51.

Marx M.C., Wood M., and Jarvis S.C., 2001. A microplate fluorimetric assay for the study of enzyme diversity in soils. Soil Biol. Biochem. 33: $1633-1640$.

McKenzie D.C. and McBratney A.B., 2001. Cotton root growth in a compacted vertisol (grey vertosol) I. Predictionusing strength measurements and 'limiting water ranges'. Aust. J. Soil Res. 39: 1157-1168.

MCPFE, 1993. Second Ministerial Conference on the Protection of Forests in Europe. General Declaration. 16-17 June 1993, Helsinki, Finland, $4 \mathrm{p}$.

Nambiar E.K.S., 1996. Sustained productivity of forests is a continuing challenge to soil science. Soil Sci. Soc. Am. J. 60: 1629-1642.

Olander L.P. and Vitousek P.M., 2000. Regulation of soil phosphatase and chitinase activity by $\mathrm{N}$ and $\mathrm{P}$ availability. Biogeochemistry 49 : 175-190.

Olsson P.A., 1999. Signature fatty acids provide tools for determination of the distribution and interactions of mycorrhizal fungi in soil. FEMS Microbiol. Ecol. 29: 303-310.

Ranger J., Bonnaud P., Bouriaud O., Gelhaye D., and Picard J.F., 2008. Effects of clear-cutting of a Douglas-fir (Pseudotsuga menziessii (Mirb.) Franco) plantation on chemical soil fertility. Ann. For. Sci. 65: 303 .

Richards L.A. and Weaver L.R., 1944. Fifteen atmosphere percentage as related to the permanent wilting point. Soil Sci. 56: 331-339.

Salas A.M., Elliott E.T., Westfall D.G., Cole C.V., and Six J., 2003. The role of particulate organic matter in phosphorous cycling. Soil Sci. Soc. Am. J. 67: 181-189. 
Sánchez-Rodríguez F., Rodríguez-Soalleiro R., Español E., López C. A., and Merino A., 2002. Influence of edaphic factors and tree nutritive status on the productivity of Pinus radiata $\mathrm{D}$. Don plantations in northwestern Spain. For. Ecol. Manage. 171: 181-189.

Sands R., Greacen E.L., and Gerard C.J., 1979. Compaction of sandy soils in radiata pine forests. I A penetrometer study. Aust. J. Soil Res. 17: 101-113.

Santruckova H., Vrba J., Picek T. and Kopacek J., 2004. Soil biochemical activity and phosphorous transformations and losses from acidified forest soils. Soil Biol. Biochem. 36: 1569-1576.

Shukla M.K., Lal R., and Ebinger M., 2006. Determinig soil quality indicators by factor analysis. Soil Tillage Res. 87: 194-204.

Siira-Pietikäinen A., Haimi J., Kanninen A., Pietikäinen J., and Fritze H., 2001. Responses of decomposer community to root-isolation and addition of slash. Soil Biol. Biochem. 33: 1993-2004.

Sinsabaugh R.L., Saiya-Cork K., Long T., Osgood M.P., Neher D.A., Zak D.R., and Norby R.J., 2003. Soil microbial activity in a Liquidambar plantation unresponsive to $\mathrm{CO} 2$-driven increases in primary production. Appl. Soil Ecol. 24: 263-271.
Smith S.E. and Read D.J., 1997. Mycorhizal Symbiosis. Academic Press, San Diego.

Stevens J.P., 2002. Applied Multivariate Statistics for the Social Sciences, 4th ed., Lawrence Erlbaum Associates, Inc., Mahwah, New Jersey.

Tabachnick B.G. and Fidell L.S., 2001. Using Multivariate Statistics, 4th ed., Allyn and Bacon, Boston, MA, USA.

Tscherko D. and Kandeler E., 1999. Biomonitoring of soils - microbial biomass and enzymatic processes as indicators for environmental change. Bodenkultur 50: 215-226.

Tscherko D., Kandeler E., and Bárdossy A., 2007. Fuzzy classification of soil microbial biomass and enzyme activity in grassland soils. Soil Biol. Biochem. 39: 1799-1808.

Waldrop M.P., MacColl J.G., and Powers R.F., 2003. Effects of forest postharvest management practices on enzyme activities in decomposing litter. Soil Sci. Soc. Am. J. 67: 1250-1256.

Zou C., Sands R., Buchan G., and Hudson I., 2000. Least limiting water range: a potential indicator of physical quality of forest soil. Aust. J. Soil Res. 38: 947-958. 